DOI: https://doi.org/10.47405/mjssh.v6i7.866

\begin{tabular}{|c|c|}
\hline 4.581 & Malaysian Journal of Social Sciences and Humanities (MJSSH) \\
\hline $\begin{array}{l}\text { Malaysian Journal of } \\
\text { Social cciences and }\end{array}$ & Volume 6, Issue 7, July 2021 \\
\hline (MJ-SSH) & e-ISSN : 2504-8562 \\
\hline & $\begin{array}{l}\text { Journal home page: } \\
\text { www.msocialsciences.com }\end{array}$ \\
\hline
\end{tabular}

\title{
Perkembangan Sektor Penghantaran Makanan ke Rumah melalui Pembelian Atas Talian Sepanjang Pandemik Covid-19 di Malaysia
}

\author{
Muhammad Zakwan Zahari' ${ }^{1}$, Muhammad Rusyaidi Razali' ${ }^{1}$, Mohamad Izzuan Mohd Ishar1 \\ ${ }^{1}$ Sekolah Pendidikan, Fakulti Sains Sosial dan Kemanusiaan, Universiti Teknologi Malaysia (UTM) \\ Correspondence: Muhammad Rusyaidi Razali (rusyaidi1998@graduate.utm.my)
}

\begin{abstract}
Abstrak
Sektor penghantaran makanan dilihat memainkan peranan yang penting kepada masyarakat bagi memutuskan rangkaian wabak pandemik Covid-19. Hal ini kerana kewujudan sektor penghantaran makanan secara tidak langsung dapat mencegah masyarakat daripada mudah terdedah kepada orang ramai serta berisiko tinggi bagi wabak tersebut berjangkit. Bukan itu sahaja, sektor penghantaran makanan juga dilihat mula mendapat perhatian dalam kalangan masyarakat kerana membuka peluang pekerjaan kepada masyarakat sekali gus dapat membantu menjana pendapatan sesebuah keluarga. Oleh itu, kajian ini bertujuan untuk mengenal pasti perkembangan sektor penghantaran makanan sepanjang pandemik Covid-19. Selain itu, kajian ini turut mengkaji aplikasi yang digunakan oleh pekerja-pekerja penghantaran makanan serta mengenal pasti strategik yang digunakan oleh sektor penghantaran makanan bagi memajukan perusahaannya. Kajian yang dijalankan melalui edaran borang soal selidik secara atas talian kepada pekerja-pekerja dalam sektor penghantaran makanan yang melibatkan Foodpanda, Grabfood dan mana-mana kedai yang menyediakan perkhidmatan penghantaran makanan ke rumah.
\end{abstract}

Kata kunci: Covid-19, penghantaran makanan, pembelian atas talian

\section{The Effect of New Norms on Consumer from the Social Aspect Activities}

\begin{abstract}
The food delivery sector is seen to play an important role in society in deciding on the Covid-19 pandemic outbreak network. This is because the existence of the food delivery sector can indirectly prevent the community from being vulnerable to the public and at high risk for the outbreak. Not only that, but the food delivery sector is also seen to be gaining attention among the community because it opens employment opportunities to the community thus helping to generate income for a family. Therefore, this study aims to identify the development of the food delivery sector throughout the Covid-19 pandemic. Besides, this study also examines the applications used by food delivery workers as well as identifies the strategies used by the food delivery sector to develop its enterprise. The study was conducted through the distribution of online questionnaires to employees in the food delivery sector involving Foodpanda, Grabfood and any store that provides home delivery service.
\end{abstract}

Keywords: Covid-19, food delivery, online buying 


\section{Pengenalan}

Pandemik Covid-19 telah mendidik rakyat Malaysia untuk hidup dalam normal baharu. Kehidupan dan aktiviti harian masyarakat kini telah banyak berubah. Salah satu bidang terkesan akibat pandemik ini adalah dalam sektor penghantaran makanan yang dibeli secara atas talian baik kawasan bandar mahupun luar bandar. Sektor penghantaran makanan merujuk kepada sesuatu institusi, agensi atau pihak-pihak tertentu yang menawarkan khidmat penghantaran makanan dan minuman yang telah siap dipesan secara atas talian dan dikenakan bayaran dengan kadar yang tertentu untuk menghantar makanan kepada pemiliknya. Penularan wabak pandemik Covid-19 dipercayai telah memberi kesan yang pelbagai kepada sektor penghantar makanan dalam pelbagai aspek seperti pengurusan masa, aspek kesihatan, keselamatan dan kemudahan. Mengikut kajian yang telah dijalankan, kami mendapati sektor penghantaran makanan mula mendapat perhatian seawal pandemik Covid-19 mula menular di Malaysia. Hal ini dikatakan demikian kerana, masyarakat mula menggunakan saluran penghantaran makanan ke rumah bagi menjamin keselamatan ahli keluarga daripada terdedah kepada tempat awam yang memudahkan virus tersebar.

Hal ini secara tidak langsung mendapat galakkan daripada pelbagai pihak kerana sektor penghantaran makanan ke rumah sekali gus membantu sektor penjualan makanan seperti kedai makan dan restoran untuk beroperasi seperti biasa walaupun perlu mengikut garis panduan yang telah ditetapkan. Menyedari perkara tersebut, akhbar-akhbar tempatan seperti Berita Harian, Metro dan sebagainya mula memuat naik berita yang baik berkaitan sektor penghantaran makanan yang begitu giat beroperasi semasa penularan wabak pandemik Covid-19. Hal ini secara tidak langsung dapat menyedarkan masyarakat setempat untuk menceburi sektor penghantaran makanan sebagai pekerjaan sambilan semasa pandemik Covid-19 menular di Malaysia. Walau bagaimanapun, penglibatan individu dalam sektor penghantaran makanan sedikit sebanyak dapat menjana pendapatan keluarga mereka kerana terdapat juga sesetengah orang yang tidak dapat bekerja lantaran penutupan beberapa sektor ekonomi akibat penularan pandemik Covid-19 yang begitu bahaya.

\section{Objektif Kajian}

Tujuan kajian ini adalah untuk:

i. Mengkaji aplikasi yang digunakan untuk berhubung bagi menjalankan pembelian atas talian sepanjang pandemik covid-19 di Malaysia.

ii. Mengenal pasti strategik pemasaran yang digunakan oleh sektor penghantaran makanan ke rumah.

\section{Kajian Literatur}

Penghantaran makanan bukanlah satu perkara yang luar biasa pada masa kini. Kini pelbagai syarikat yang menyediakan servis penghantaran makanan. Sudah tentu khidmat penghantaran makanan ketika ini menjadi pilihan utama orang ramai untuk mendapatkan makanan tanpa perlu keluar rumah. Servis penghantaran makanan kini menjadi penghubung diantara pelanggan dan peniaga dalam mencegah Covid-19 ini. Hal ini dapat membantu Negara dalam membantu pihak kerajaan menangani wabak Covid-19. Di Malaysia, banyak peluang pekerjaan dibuka dalam servis penghantaran lebih-lebih lagi pada masa kini. Dapat dilihat jumlah pekerja servis penghantaran makanan ini makin bertambah kerana peluang pekerjaan dalam sektor lain terhad dan ramai yang telah diberhentikan kerja dalam menyeimbangkan ekonomi syarikat mereka.

Perkhidmatan penghantaran makanan menjadi pilihan ramai ketika bermulanya wabak virus pandemik Covid-19. Pertubuhan Kesihatan Sedunia (WHO) telah mengesahkan bahawa korona virus baharu menjadi penyebab penyakit pernafasan sekelompok penduduk di Bandar Wuhan, Wilayah Hubei, China, yang dilaporkan kepada WHO pada 31 Disember 2019. Penularan wabak yang tinggi menyebabkan kejatuhan ekonomi, kehilangan pekerjaan, perubahan norma kehidupan dan banyak lagi. 
Oleh yang demikian, kajian ini dijalankan bagi melihat tentang perkembangan sektor penghantaran makanan ke rumah melalui pembelian atas talian sepanjang pandemik Covid-19 di Malaysia.

\section{Metod Kajian}

Kajian ini merupakan satu kajian deskriptif. Kajian ini menggunakan reka bentuk kajian kuantitatif dan borang soal selidik sebagai instrumen. Sasaran responden kajian ini ialah pekerja-pekerja yang bekerja dalam sektor penghantaran makanan. Maklumat tersebut kemudian dianalisis untuk mencapai oebjektif kajian ini. Borang soal selidik telah diedarkan secara atas talian kepada pekerja GrabFood, Foodpanda dan mereka yang menjalankan penghantaran makanan ke rumah. Jumlah populasi dalam kajian ini ialah seramai 20 orang. Borang soal selidik tersebut mengandungi tiga bahagian, iaitu Bahagian A maklumat responden, Bahagian B mengkaji aplikasi yang digunakan untuk berhubung bagi menjalankan pembelian atas talian sepanjang pandemik dan Bahagian $\mathrm{C}$ kaedah pemasaran yang digunakan oleh sektor penghantaran makanan ke rumah. Borang soal selidik menggunakan skor skala Likert dari 1 hingga 4, iaitu 1 (sangat tidak setuju), 2 (tidak setuju), 3 (setuju), 4 (sangat setuju).

\section{Analisis Kajian}

\section{Analisis Demografi kajian}

Maklumat responden penting dalam kajian kerana maklumat tersebut menceritakan maklumat dan latar belakang responden untuk kajian. Latar belakang responden berbeza dapat memberi pandangan yang unik terhadap isu perbincangan tersebut. Responden dalam kajian ini terdiri daripada 19 orang pekerja lelaki dan 1 orang pekerja perempuan. Dari segi tahap pencapaian akademik pula, responden terdiri daripada mereka yang berkelulusan Sijil Pelajaran Malaysia (SPM) (10 orang responden), Diploma (5 orang responden) dan Sarjana Muda (5 orang).

\section{Analisa maklum balas aplikasi yang digunakan untuk berhubung bagi menjalankan pembelian atas talian sepanjang pandemik Covid-19 di Malaysia}

Bagi mengkaji aplikasi yang digunakan untuk berhubung bagi menjalankan pembelian atas talian, 8 item soalan telah dibina bagi mengkaji saluran yang digunakan untuk berhubung bagi menjalankan perniagaan atas talian sepanjang pandemik Covid-19 di Malaysia dalam talian.

Jadual 1: Aplikasi penghantaran makanan

\begin{tabular}{|c|c|c|c|c|c|c|}
\hline \multirow{2}{*}{\multicolumn{2}{|c|}{ PERNYATAAN }} & \multicolumn{4}{|c|}{ KEKERAPAN DAN PERATUSAN } & \multirow[t]{3}{*}{ Purata } \\
\hline & & \multirow{2}{*}{$\begin{array}{l}\text { STS } \\
\text { Bil. } \\
\%\end{array}$} & \multirow{2}{*}{$\begin{array}{l}\text { TS } \\
\text { Bil. } \\
\%\end{array}$} & \multirow{2}{*}{$\begin{array}{l}S \\
\text { Bil. } \\
\% \\
\end{array}$} & \multirow{2}{*}{$\begin{array}{l}\text { SS } \\
\text { Bil. } \\
\%\end{array}$} & \\
\hline & & & & & & \\
\hline 1 & Aplikasi yang disediakan senang dan mudah & 0 & 0 & 5 & 15 & 3.75 \\
\hline & difahami. & 0 & 0 & 25.0 & 75.0 & \\
\hline 2 & Selain aplikasi yang disediakan, penggunaan & 1 & 4 & 9 & 6 & 3.00 \\
\hline & aplikasi lain masih diperlukan. & 5.0 & 20.0 & 45.0 & 30.0 & \\
\hline 3 & Terdapat beberapa kesukaran bagi & 10 & 10 & 0 & 0 & 1.50 \\
\hline & menggunakan aplikasi tersebut. & 50.0 & 50.0 & 0 & 0 & \\
\hline 4 & Aplikasi tersebut memudahkan pekerja & 0 & 0 & 4 & 16 & 3.80 \\
\hline & berhubung dengan pelanggan. & 0 & 0 & 20.0 & 80.0 & \\
\hline 5 & Sebarang pesanan boleh diterima dengan & 0 & 4 & 9 & 7 & 3.15 \\
\hline & cepat dan mudah. & 0 & 20.0 & 45.0 & 35.0 & \\
\hline
\end{tabular}


DOI: https://doi.org/10.47405/mjssh.v6i7.866

\begin{tabular}{|c|c|c|c|c|c|c|}
\hline 6 & Terdapat pelbagai isu berkaitan aplikasi yang & & & & 0 & 1.80 \\
\hline & digunakan. & 60.0 & 30.0 & 20.0 & 0 & \\
\hline 7 & Aplikasi yang digunakan sentiasa dikemas- & 0 & 0 & 12 & 8 & 3.40 \\
\hline & kini dengan maklumat yang terbaharu & 0 & 0 & 60.0 & 40.0 & \\
\hline 8 & $\begin{array}{l}\text { Terdapat beberapa penambah baik kepada } \\
\text { anlikasi vano digunakan }\end{array}$ & 1 & $\begin{array}{l}3 \\
150\end{array}$ & & 7 & 3.10 \\
\hline
\end{tabular}

Nota: STS = Sangat Tidak Setuju, TS = Tidak Setuju, S = Setuju, SS = Sangat Setuju

Jadual 1 di atas menyatakan kekerapan, peratus dan purata bagi 8 item soalan yang telah dibina untuk mengenal pasti tahap aplikasi yang digunakan untuk berhubung bagi menjalankan perniagaan atas talian dalam sektor penghantaran makanan. Berdasarkan jadual, empat item menunjukkan peratusan setuju tertinggi iaitu pada item soalan dua, lima, tujuh dan lapan manakala merujuk kepada item nombor 3 yang mencatatkan jumlah sangat tidak setuju dan tidak setuju yang sama dan seimbang iaitu sebanyak 50 peratus. Bagi keseluruhan item, terdapat dua item yang mencatatkan bilangan sangat setuju yang tertinggi iaitu pada item bernombor 1 iaitu sebanyak 15 orang bersamaan 75 peratus dan item bernombor 4 sebanyak 16 orang bersamaan 85 peratus. Hal ini secara tidak langsung menunjuk terdapat beberapa kelebihan yang menyebabkan masyarakat sangat setuju dengan saluran yang digunakan sekarang. Malahan terdapat juga sangat tidak setuju yang merekodkan bilangan paling tinggi iaitu sebanyak 12 orang bersamaan 60 peratus pada item yang keenam dimana mereka sangat tidak setuju kerana terdapat banyak isu berkaitan dengan aplikasi yang digunakan.

\section{Analisa Maklum Balas Strategik Pemasaran Yang Digunakan Oleh Sektor Penghantaran Makanan Ke Rumah.}

Bagi mengenal pasti strategik pemasaran yang digunakan oleh sektor penghantaran makanan ke rumah, 7 item soalan telah. Jadual 2 menunjukkan dapatan kajian bagi setiap item untuk mengkaji strategik pemasaran yang digunakan.

Jadual 2: Strategik sektor penghantaran makanan

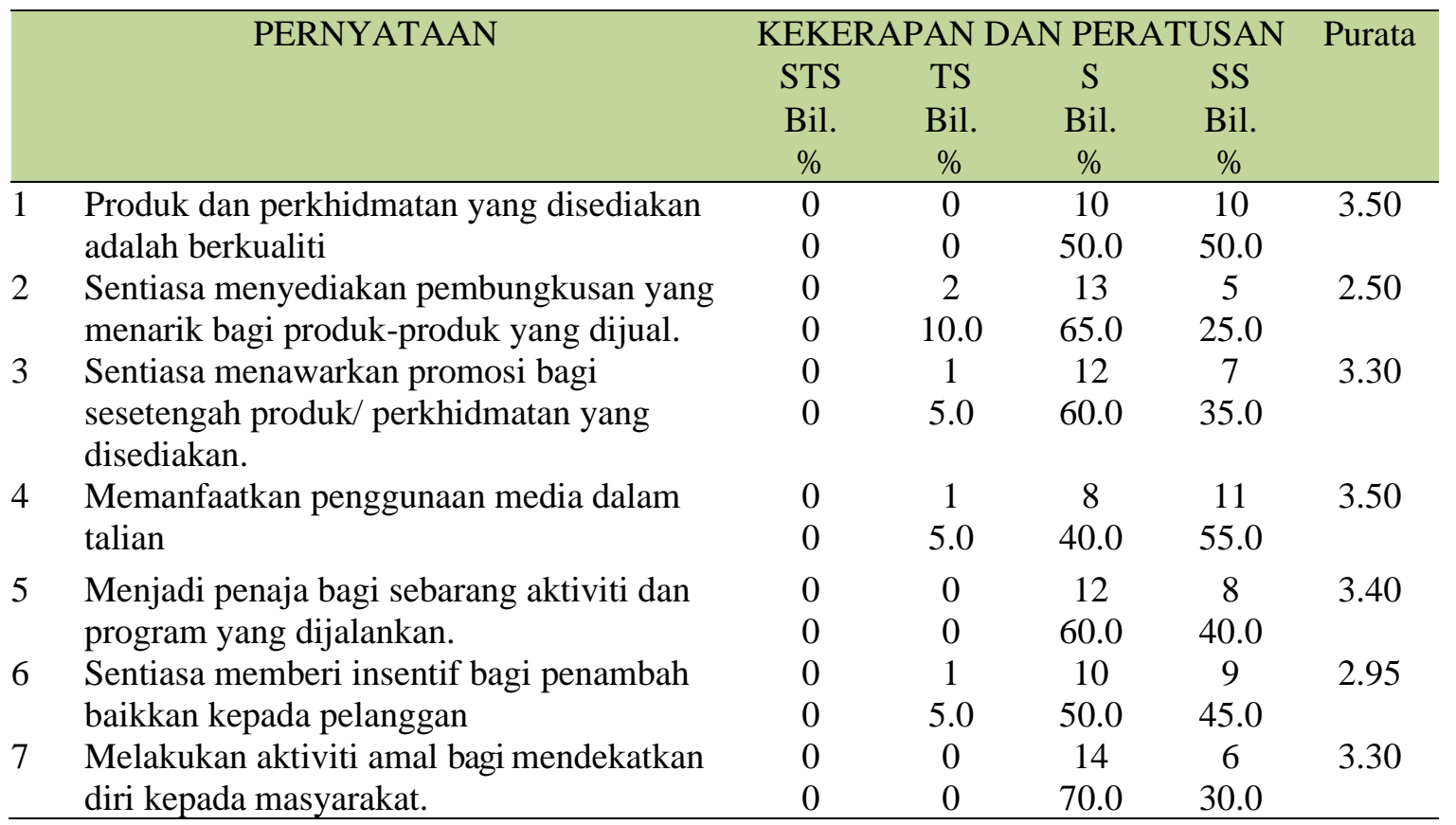

Nota: STS = Sangat Tidak Setuju, TS = Tidak Setuju, S = Setuju, SS = Sangat Setuju 


\section{Kesimpulan dan Cadangan}

Objektif utama penyelidikan ini adalah untuk mengenal pasti perkembangan sektor penghantaran makanan ke rumah melalui pembelian atas talian sepanjang pandemik Covid-19 di Malaysia. Kajian ini telah mengumpulkan maklumat mengenai saluran dan kaedah yang digunakan bagi sektor penghantaran makanan berhubung dengan pelanggan sepanjang pandemik Covid -19. Hasil kajian kami mendapati semua responden dalam sektor penghantaran makanan sangat setuju banyak sektor penghantaran makanan menggunakan strategik produk dan perkhidmatan yang disediakan adalah berkualiti dan memanfaatkan penggunaan media dalam talian. Kami juga telah mendapati bahawa terdapat responden yang ingin penambahbaikan kepada sistem GPS Aplikasi Roadrunner. Selain itu, kajian ini juga dapat mengenal pasti beberapa strategik yang telah dilakukan oleh sektor-sektor penghantaran makanan di Malaysia bagi memastikan sektor dan perkhidmatan mereka mendapat perhatian terutamanya semasa pandemik Covid-19 di Malaysia.

\section{Rujukan}

Aling, Y. D. (2020,March 24). Operasi bas Ekspres diteruskan. Retrieved from https://www.hmetro.

Astro Awani (n.d.). Retrieved from https://www.astroawani.com/berita-malaysia/penghantarmakanan- depani-risiko-demi-menjaga-perut-pelanggan-234341

Berita Harian (2020, March 21). COVID-19: Khidmat penghantaran bantu pengusaha restoran, orang ramai. Retrieved from https://www.bharian.com.my/berita/nasional/2020/03/667475/covid-19khidmat-penghantaran-bantu-pengusaha-restoran-orang-ramai com.my/mutakhir/2020/03/558022/operasi-bas-ekspres-diteruskan

Dagang News (n.d.). KFC, Pizza Hut boleh ditempah menerusi GrabFood. Retrieved from https:// dagangnews.com/kfc-pizza-hut-boleh-ditempah-menerusi-grabfood

Harian Metro. (n.d.). PKP: Beli makanan biar ada strategi . Retrieved from https://www.hmetro.com.

Hassan, N. (2020, March 17). Covid-19: Pemandu Grab tingkatkan langkah keselamatan. Retrieved January 20, 2021, from https://www.sinarharian.com.my/article/74116/KHAS/Covid-19/Covid19-Pemandu-Grab- tingkatkan-langkah-keselamatan my/rencana/2020/04/569365/pkp-beli-makanan-biar-ada-strategi

Shuib, N. (2019, February 13). Khidmat penghantaran makanan jimatkan masa. Retrieved January 20, 2021, from https://www.bharian.com.my/wanita/lain- lain/2019/02/530297/khidmatpenghantaran-makanan-jimatkan-masa

Utusan Borneo (2020, April 16). Buat yang terbaik semasa PKP untuk menjana pendapatan. Retrieved January 20, 2021, from https://www.utusanborneo.com.my/2020/04/16/buat-yang-terbaiksemasa-pkp-untuk-menjana-pendapatan 